Olena Bilhorodska,

PhD (Candidate of Pedagogical Sciences), associate professor, Department of Drawing, Painting and Architectural Graphics,

Kateryna Kucherenko, teaching assistant, Department of Drawing, Painting and Architectural Graphics, Odessa State Academy of Civil Engineering and Architecture, 4, Didrikhsona Str., Odesa, Ukraine

\title{
SOME ASPECTS OF COMPOSITIONAL THINKING OF FUTURE ARCHITECTS IN ART EDUCATION
}

The paper is focused on one of the major architectural disciplines, Composition, which is closely related to drawing, painting, history of arts, colour science, aesthetics, and philosophy. The research aims to prove and analyse the reasonability of forming compositional thinking in the system of art education of future architects. Compositional thinking is considered as an independent kind of mental activity, since it involves compositional mental process with its operations and final result, which is the basis for creative and imaginative thinking. Theoretical knowledge obtained by students studying the subject "Drawing, Painting, Sculpture" is the basis for professional deep understanding of the rules, principles and means of artistic and compositional shaping of artificial systems as an essential component of a student's professional competence and creative thinking. This theoretical and practical knowledge enables future artists or architects to estimate aesthetic and imaginative value of compositional artworks, gain an insight of their harmonious composition, be fully aware of the mechanisms of these work's impact on the sphere of human emotions and feelings. While dealing with artistic and compositional tasks provided by the training course, students' compositional thinking is activated, their creative potential is developed. The latter implies comprehensive understanding of the problematic area of an architect's or artist's activities and correlating it with the system of methodological principles of solving certain problem situations in his/her career.

Keywords: architectural education, composition, compositional thinking, art education, drawing.

Introduction. One of the major tasks of contemporary education is the qualitative change of the system of training specialists, which is focused on the high level of development of their thinking corresponding to their profession. The quality of future architects' work is determined by the combination of the acquired scientific theoretical knowledge, abilities and skills in composition as well as the ability to deal with creative tasks. Therefore, the formation of compositional thinking in the process of teaching composition to students indicates the quality of professional training, is a creative tool and a means of creative personality becoming.

One of the main features of spatial thinking in an architect's creative work is the skills of creating an illusory image of a designed project on a sheet of paper. In this case, two things should be taken into account: "geometrical representation" of the depicted real space and the perceptive space.

The issues of training architects were studied by B. Barkhin, O. Hutnov, O. Stepanov. The research works of P. Halperin, V. Davydov, O. Denysov, L. Zankov, I. Zymnia, I. Lerner, O. Matiushkin, R. Niemov, M. Makhmutov, D. Elkonin, et al. covered the aspects of the activation of learning and cognitive activity in contemporary educational system. Theoretical basis for the organisation of training architects by means of fine arts was formed in the works of $\mathrm{H}$. Bida, V. Lebedko, V. Kuzin, N. Rostovstev, E. Shorokhov, and others. Con- temporary practice of art education incorporates a great number of methods aimed at the development of creative (compositional) thinking. Experience of their use is represented in special methodological and scientific works of N. Beschastnova, K. Dahldiian, N. Nikonenko, H. Lohvynenko, H. Panksionov, M. Surin, N. Tretiakov, and others. Theoretical aspect of composition is based on the researches of M. Alpatov, Ye. Adamov, R. Arnkheim, V. Asmus, N. Volkov, V. Kandynskyi, Ye. Kibrik, A. Losiev, Yu. Lotman, B. Raushenbakh, A. Svieshnikov, N. Tretiakov, V. Favorskyi, and others.

High priority is placed on teaching composition, as future specialists often have to deal with compositional tasks in their work. Compositional proficiency is the basis for creative professionalism of any specialist of arts (an artist, a designer, an architect). Composition course is naturally related to all profession-related disciplines of the curriculum.

The development of compositional thinking is also connected with other psychological attributes of a personality - capabilities, memory, imagination, working style, etc., which makes it possible to consider the development of future specialists' creative potential to be based on the formation of their general compositional culture. Insufficient theoretical information about the issues of compositional thinking, the need for training practice in the formation of architect's creative personality and dependence of students' creative development on the maturity of 
compositional thinking are the aspects that determined the relevance of the study.

The paper aims to prove and analyse the reasonability of forming compositional thinking in the system of art education of future architects.

Discussion. Artistic vision is the basis for an architect's specific thinking and considered to be the central category of professional thinking from the standpoint of architectural space. The most important psychological trait of an architect's professionalism is the specific imagery of his/her thinking, specific quality of perception and vision of spatial environment. The discipline "Composition" is different from other art disciplines, as it combines and updates knowledge concerning fine arts. In $\mathrm{N}$. Krymova's opinion, composition as "a creative organisation of a picture" is employed for bringing an artist's or architect's ideas to life, so searching for formula is the main creative task that helps to achieve a goal [3].

One of the characteristic features of art education of students majoring in architecture is its orientation at mastering expressive means of picturing regardless of its figurative basis. It is explained by the fact that in architecture non-figurative geometrical structures appear as constructive objects with certain functional properties. Accordingly, the mastering of graphical means of depicting by architecture students involves learning academic literacy of painting/drawing from nature and first of all compositional principles of abstract forms' structuring.

The curriculum for the speciality "Architecture and Urban Planning" does not include the course "Composition", though its relevance is obvious. Therefore, it should be introduced at Drawing lessons in the form of certain compositional tasks and exercises. These tasks are to be done within the established system of limitations for depicting the elements of the form: point, splodge, line, plane, volume, space. Work on them is regulated by curriculum hours, most of which are allocated for independent creative work that involves discussion of layouts at individual and group consultations.

Composition is considered as a creative process and its main component is handling intellectual images: the processes of dissociation and association, analysis and synthesis, comparison and generalisation, emergence of images related to perception, imagination, fantasy accompanied by empathy and identification. Solving all the compositional problems (achieving integrity and balance, conveying space, movement, etc.) facilitates developing a theme and creating artistic image in a composition. In the process of creating a composition, a certain type of thinking characterised by using artistic expression means is being developed.

V. Kanunnikova defines composition as visualisation of an artistic image using expressive means of art and associates it with a certain type of thinking that is focused on solving compositional problems with the use of expressive artistic means. Considering the character of tasks performed by the way of thinking under study (compositional tasks), the content (the use of images) and aim of the work (developing a theme and creating an artistic image), this way of thinking should be defined as compositional creative thinking [3].

Architects, artists-teachers, psychologists and others believe that the concept "compositional thinking" involves cognitive and mental functions oriented at the eventual result - creating an image in accordance with compositional rules.

For example, L. Pankratova in her research work proves that compositional thinking is the establishing of spatial-temporal relations of an image, which are determined by the worldview peculiar to the epoch in general and the artist in particular [9]. In the research work of V. Iliushchenko, compositional thinking is considered as a kind of creative thinking, which is based on using memory images, perceptions, imagination. Generally, compositional thinking is understood as a component of other types of thinking related to it: creative and imaginative. The latter is defined as a process of artistic cognition consisting of interrelated components (emotional, logical, intuitive), which results in an artistic image reflecting the ability of a person to distinguish the essence of real life phenomena; generalise, create artistically significant image and render this ideal image into the language of pictorial art, graphic art, sculpture, etc. [2].

However, thinking does not exist as a separate mental process, it is a component of other cognitive processes: perception, attention, imagination, memory, language. "Higher forms of these processes are always related to thinking, and the degree of involvement of these processes determine the level of their development", R. Nemov thinks [7]. R. Arheim notes that the elements of thinking in perception and perception as an element of thinking complement each other. They turn human cognition into a single process $[1 ; 7]$. Compositional thinking of an artist or an architect dominates over other types of thinking in the very process of compositional activities, which is obvious in the process of solving compositional problems. "All types of human thinking coexist and can be represented in the same activity. However, depending on its character and final objective, a certain type of thinking dominates. This is the basis for distinguishing these types", R. Nemov notes [7].

It is worth noting that an artist's thinking in the process of compositional activities can be verbally-logical, practical and image-bearing. Therefore, compositional thinking includes theoretical and practical compositional activities related to cognitive, research and converting actions. In-depth study of compositional categories starting from the early period of its becoming was conducted by A. Svieshnikov [11]. He distinguished four groups of individually psychological peculiarities of compositional thinking: projective and divisional, projective and stereotyped, distortive and divisional, distortive and stereotyped. Projective character is defined by the researcher as a determination to create the most recognisable image. Distortive interpretation conveys information about the subject figuratively. In the first group of students he ob- 
served obvious primitiveness of imaginative compositional thinking. Thus, it can be concluded that in this case it is more important to develop formal compositional thinking. On the one hand, it is facilitated by the exercises aimed at creating abstract and decorative compositions, and on the other hand - by the exercises aimed at finding compositional patterns through analysing realistic artworks [11].

For this purpose, it is reasonable to use exercises that involve crating small abstract and decorative fragments according to initially given patterns or prepared samples. Logically correct tasks and exercises developed to achieve balance on the plane (using geometric figures, plane articulation, rhythm, symmetry and asymmetry, centrepiece, etc.) gradually form students' elementary compositional abilities and skills and develop them as creative personalities. Below are the examples of the exercises aimed at organising balance on the plane using common geometric figures and plane division (articulation).

Exercise 1. Create a properly arranged composition consisting of simple geometric figures (a circle, a square, a triangle, a diamond) taking into account their simplicity and stability. Find their optimal position on the reference plane. Objectives: To achieve balance between the plane and the image.

Material: Dark coloured paper of A4 size.

Exercise 2: Balance out the figures of regular geometric shapes (a circle, a square, a triangle, a diamond), find their optimal position on the reference plane, add a figure contrasting in colour to the composition. Use knowledge about the significance of colour. Objective: To master skills of organising balance between the plane and the image.

Material: Dark coloured paper, red paper of A4 size.

Methodical comment: Any properly arranged composition is balanced. Balance is the arrangement of elements of a composition, whereby each element occupies stable position. Its position causes no doubt or desire to move it within the plane being depicted. When dealing with the issues of balance in a composition, it is important to consider placement of its elements: significance of a subject depends on its placement. Balance of depicted elements can be static (for a symmetrical composition) and dynamic (for an asymmetrical composition). Global principle of balance and harmonisation of depicted elements, the fundamental law of a composition is the integrity of internal organisation (hierarchy of forms - masses, movements, etc., distinguishing the central ones among them). Balance of composite masses is achieved by means of the "lever principle" (the same as in physics): a small element can balance a large figure if it is located on the periphery of the image (farther from its geometric centre) and is contrastive. It is necessary to take into account the compositional structure of the layout: right and top of the picture are "lighter" and should be less "loaded" to achieve balance, because the main optical centre of the composition is shifted upward to the right in accordance with the geometric centre. The element that is at the cen- tre of the composition, or close to it, or is on the vertical central axis is less significant on a compositional level than the element that is outside these main lines. Conformity of an image with the lines of composition's structural plan brings in an element of stability. Formal compositions can consist of elements of different configurations. In this case, it is necessary to determine the position of each figure correctly depending on its form.

1. Compact images look heavier.

2. A diagonal in a square drawn from the bottom left to the top right corner is perceived as rising.

3. A diagonal in a square drawn from the top left corner to the bottom right is considered as descending.

4. A square in a stable position is the "heaviest" figure; this property can be intensified or softened by colour.

5. A triangle as the most "sweeping" form for perception is stable only when one side of it is horizontal. All dynamic figures tend to a triangle.

6. A circle is a form focused on itself; it combines outermost and centripetal force, circular motion. Having no stable basis, a circle is always unstable.

Exercise 3: Create a composition consisting of three simple geometric figures (a triangle, a circle, a square or a rectangle) using a simple division of the plane with straight lines. You may use the exercise 1 from the topic "Organisation of balance on the plane with simple geometric figures". Objective: To use plane division with the dual purpose: to achieve balance and to combine subjects in one composition.

Exercise 4: Create a balanced composition consisting of three simple geometric figures (a triangle, a circle, a square or a rectangle) using complex division of the plane with parabolic curves and lines. You may use the exercise 1 from the topic "Organisation of balance on the plane with simple geometric figures". Both tasks are to be placed on the same paper. Objective: To use plane division with the dual purpose: to achieve balance and to combine subjects in one composition.

Methodical comment: Division (articulation) of the plane involves the establishment of various relationships in terms of colour or tone between the parts, whose competent use makes it possible to achieve desired balance in the composition. The division of the plane into parts is a compositional tool for achieving balance in the composition in case the regrouping of the elements is unacceptable or insufficient. This tool is used in combination with other expressive means. If these relations are based on the same parts, there will appear an element of statics; if they are based on different parts, there will be an element of dynamics. The division is carried out with straight or curved lines and maintained with colour or tone. Division in one or more directions is possible. The division with straight lines is simple, division with parabolic lines looks different as they convey tension themselves, and there is a need to combine contradictory straight and curved movements in one plane.

Compositional search is characterised by active creative intellectual work aimed at finding a visual embodi- 
ment of the image. Searching compositional work activates sensory (intuitive, emotional) perception and analytical (rational) thinking in their relationship. For example, compositional thinking makes it possible to distinguish comprehensive phenomena from their empirical variety, identify the essential and reject the random, see the invisible, connect the asynchronical in a single artistic projection, reconstruct figurative continuity of the fragmented reality and find the point of balance, harmony of the objective world [10].

The formation of compositional thinking is based on certain pedagogical and methodical principles and aspects.

1. Compositional thinking is being formed gradually in the continuous educational process based on permanent figural activity.

2. Activation of the process of compositional thinking development is achieved by means of engaging students in performing specially organised compositional work.

3. Students' creative capabilities are being developed when doing tasks in the system of educational and compositional activity that is gradually becoming more complicated and aimed at gradual mastering of the study material on the level of reproduction, compositional experimenting using the example, freer transformation of the perception object on the productive level followed by reaching one's own creative level of compositional activity.

4. The process of students' compositional capabilities development will become controlled in case the system of learning activities has been developed in compliance with the didactic principles of consistency and gradual complication of the study material. The content of theoretical and practical parts of "Composition" course should correspond to the complexity of students' compositional activities.

5. The main condition for the successful development of students' creative capabilities is pedagogical organisation of their compositional activities, which corresponds to the content of training.

6. Intensive development of students' compositional capabilities depends greatly on their motivational readiness for compositional creativity, aptitude for this kind of activities $[4 ; 5 ; 6 ; 8 ; 10 ; 12]$.

\section{REFERENCES}

1. Arnkheim, R. (1981). Vizualnoye myshleniye. Khrestomatiya po obschey psikhologii. Psikhologiya myshleniya [Visual thinking. General psychology reader. Psychology of thinking]. Yu. B. Gippenreiter, V. V. Petukhova (Eds.). Moscow: Izd-vo MGU [in Russian].

2. Bilhorodska, O. Ye. (2014). Metodychni vkazivky do orhanizatsii samostiinoi roboty studentiv I kursu za temamy formalnoi kompozytsii z dystsypliny "Rysunok", napriam pidhotovky 6.060102 "Arkhitektura" osvitnokvalifikatsiinyi riven «bakalavr» [Guidelines for selfguided work of first-year students (Bachelor's degree) majoring in "Architecture" on formal composition topics
Conclusions. Thus, compositional thinking is considered as an independent kind of mental activity, since it involves compositional mental process with its operations and final result, which is the basis for creative and imaginative thinking. Theoretical knowledge obtained by students studying the subject "Drawing, Painting, Sculpture" is the basis for professional deep understanding of the rules, principles and means of artistic and compositional shaping of artificial systems as an essential component of a student's professional competence and creative thinking. This theoretical and practical knowledge enables future artists or architects to estimate aesthetic and imaginative value of compositional artworks, gain an insight of their harmonious composition, be fully aware of the mechanisms of these work's impact on the sphere of human emotions and feelings.

The society puts forward tough requirements for the quality of architects' training. The society's demand is oriented first of all at the specialist who is capable of understanding and evaluating the subject under study from different points of view; able to find a creative approach to solving creative problems, see the unity of all its relations, adapt quickly when dealing with topical socio-cultural issues; understand social development rules; project material three-dimensional environment at the high artistic and imaginative level taking into account the principles of architectural solutions: usefulness, reliability, beauty. Systemic character of thinking is the main feature of an architect's professional and creative thinking, which is determined by all-round and wide variety of his/her activities in science, art and technology. A high diversity of learning and creative activities of architectural and civil engineering education is characterised by versatile character of exploring three-dimensional environment.

While dealing with artistic and compositional tasks provided by the training course, students' compositional thinking is activated, their creative potential is developed. The latter implies comprehensive understanding of the problematic area of an architect's or artist's activities and correlating it with the system of methodological principles of solving certain problem situations in his/her career.

The study has not covered all the issues related to the topic, so further research in this area is considered to be relevant.

during Drawing classes]. Odessa: Astroprynt [in Ukrainian].

3. Ilyushchenko, V. L. (2000). Aktivizatsiya kompozitsionnogo myshleniya studentov khud.-graf. fakultetov na zaniatiyakh po risunku portreta [Activating compositional thinking in graphic arts students during portrait lessons]. Candidate's thesis. Moscow [in Russian].

4. Kanunnikova, T. A. (2016). Metodika razvitiya kompozitsionno-obraznogo myshleniya podrostkov sredstvami izobrazitelnogo iskusstva [Developing compositional and creative thinking in adolescents by means of fine arts]. Candidate's thesis. Moscow [in Russian]. 
5. Kisileva V. A. (2002). Metodicheskie osnovy professionalnoi podgotovki arkhitektora sredstvami izobrazitelnogo iskusstva [Methodological foundations of professional architectural training by means of fine arts]. Extended abstract of candidate's thesis. Tambov [in Russian].

6. Minsabirova, V. N. (2015). Formirovanie kompozitsionnogo myshleniya studentov $\mathrm{v}$ protsesse izucheniya formalnoy kompozitsii [Forming compositional thinking of students when teaching formal composition]. Nauchnye issledovaniya: ot teorii k praktike - Scientific research: from theory to practice: Proceedings of the $4^{\text {th }}$ International research and practice conference, 5 (6), 117-119. Cheboksary "Interaktiv plus" [in Russian].

7. Nemov, R. S. (2001). Psikhologiia. Kniga 1: $O b-$ shchie osnovy psikhologii [Psychology. Book 1: Fundamentals of psychology]. $4^{\text {th }}$ ed., rev. Moscow [in Russian].

8. Nikitenkov, S. A. (2000). Kompozitsionnoe myshlenie kak faktor tvorcheskogo razvitiya studentov khudozhestvenno-graficheskogo fakulteta [Compositional thinking as a factor of creative development of fine arts and graphic design students]. Candidate's thesis. Lipetsk [in Russian].

9. Pankratova L. I. (1998). Formirovanie kompozitsionnogo myshleniya studentov fakulteta peda-

\section{ЛІТЕРАТУРА}

1. Арнхейм Р. Визуальное мышление. Хрестоматия по общей психологии. Психология мышления / Под ред. Ю. Б. Гиппенрейтер, В. В.Петухова. - М. : Изд-во МГУ, 1981. - С. 97-107.

2. Білгородська О. С. Методичні вказівки до організації самостійної роботи студентів I курсу за темами формальної композиції з дисципліни «Рисунок», напрям підготовки 6.060102 «Архітектура» освітньокваліфікаційний рівень «бакалавр» / Олена Свгеніївна Білгородська. - Одеса : Астропринт, 2014. - 40 с.

3. Илющенко В. Л. Активизация композиционного мышления студентов худ.-граф. факультетов на занятиях по рисунку портрета : дисс. ... канд. пед. наук : 13.00.02. - теория и методика обучения изобразительному искусству / Моск. пед. гос. ун-т. - М., 2000. - 154 c.

4. Канунникова Т. А. Методика развития композиционно-образного мышления подростков средствами изобразительного искусства: дис. ... канд. пед. наук : 13.00.02. - теория и методика обучения и воспитания (изобразительное искусство) / Татьяна Александровна Канунникова. - Москва, 2016. - 275 с.

5. Кисилёва В. А. Методические основы профессиональной подготовки архитектора средствами изобразительного искусства : автореф. дис. ... канд. пед. наук : спец. 13.00.02. - «Теория и методика обучения и воспитания (изобразительное искусство, уровень профессионального образования)» 13.00.08, «Теория и методика профессионального образования» / Вера Алексеевна Кисилёва. - Тамбов, 2002. - 25 с. gogiki i metodiki nachalnogo obrazovaniya vuza na zaniatiyakh izobrazitelnym iskusstvom [The formation of compositional thinking in students majoring in primary education at fine arts classes]. Candidate's thesis. Moscow [in Russian].

10. Sadomova, N. I. (2015). Nekotorye voprosy razvitiya kompozitsionnogo myshleniya studentovdizaynerov [Some issues of compositional thinking development in students-designers]. Pedagogika iskusstva Art pedagogy, 2. Retrieved from: http://www.arteducation.ru/electronic-journal/nekotorye-voprosyrazvitiya-kompozicionnogo-myshleniya-studentovdizaynerov [in Russian].

11. Sveshnikov, A. V. (2004). Kompozitsionnoe myshlenie $\mathrm{V}$ izobrazitelnom iskusstve [Compositional thinking in fine arts]. Extended abstract of doctor's thesis. St. Petersburg [in Russian].

12. Chernaya, Ye. A. (2006). Razvitie kompozitsionnogo myshleniya studentov-arkhitektorov $\mathrm{v}$ protsesse izucheniya distsipliny «Risunok» (na primere zadaniya "Arkhitekturnaia panorama") [Developing compositional thinking in architecture students at Drawing classes (using the Architectural Panorama task as an example)]. Extended abstract of candidate's thesis. St. Petersburg [in Russian].

6. Минсабирова В. Н. Формирование композиционного мышления студентов в процессе изучения формальной композиции / В. Н. Минсабирова // Научные исследования : от теории к практике : материалы VI Междунар. науч.-практ. конф. (Чебоксары, 31 дек. 2015 г.) / редкол.: О. Н. Широков [и др.]. Чебоксары : ЦНС «Интерактив плюс», 2015. - № 5 (6). - C. 117-119.

7. Немов Р. С. Психология. Кн. 1 : Общие основы психологии / Роберт Семёнович Немов. - 4-е изд. Москва : Владос ИМЭПЭ им. Грибоедова, 2001. - 688 c.

8. Никитенков С. А. Композиционное мышление как фактор творческого развития студентов художественно-графического факультета : дис. ... канд. пед. наук : 13. 00.08 - Теория и методика профессионального образования / Сергей Алексеевич Никитенков. Липецк, 2000. - 239 с.

9. Панкратова Л. И. Формирование композиционного мышления студентов факультета педагогики и методики начального образования вуза на занятиях изобразительным искусством : дисс. ... канд. пед. наук : 13.00.02 -«Теория и методика обучения изобразительному искусству» / Л. И. Панкратова. - Моск. пед. госун-т. - М., 1998. - 229 с.

10. Садомова Н. И. Некоторые вопросы развития композиционного мышления студентов-дизайнеров [Электронный ресурс] / Наталья Ивановна Садомова // Педагогика искусства. - 2015. - №2. - Режим доступа : : http://www.art-education.ru/electronic- 
journal/nekotorye-voprosy-razvitiya-kompozicionnogomyshleniya-studentov-dizaynerov.

11. Свешников А. В. Композиционное мышление в изобразительном искусстве : автореф. дис. ... докт. наук по искусствоведению : спец. 17.00.09 «Теория и история искусств» / Александр Вячеславович Свешников. - Санкт-Петербург, 2004. - 52 с.

12. Черная Е. А. Развитие композиционного мышления студентов-архитекторов в процессе изуче- ния дисциплины «Рисунок» (на примере задания «Архитектурная панорама») : автореф. дис. ... канд. пед. наук : спец. 13.00.02 «Теория и методика обучения и воспитания (изобразительное и декоративноприкладное искусство, уровень профессионального образования)» / Елена Александровна Черная. Санкт-Петербург, 2006. - 23 с.

Олена Свгеніївна Білгородська, кандидат педагогічних наук, доцент кафедри рисунка, живопису та архітектурної графіки,

Катерина Панасівна Кучеренко, асистент кафедри рисунка, живопису та архітектурної графіки, Одеська академія будівниитва та архітектури, вул. Дідріхсона 4, м. Одеса, Украӥна

\section{АСПЕКТИ КОМПОЗИЦЙНОГО МИСЛЕННЯ МАЙБУТНІХ АРХІТЕКТОРІВ У ПРОЦЕСІ ХУДОЖНЬОЇ ОСВІТИ}

Особливістю художнього навчання студентів, які здобувають архітектурну спеціальність, є їі орієнтація та спрямованість на опанування виразними засобами зображення незалежно від його фігуративної основи, оскільки в архітектурі безпредметні геометричні форми виступають як конструктивні об'єкти, що мають певні функціональні властивості. Тому опанування студентами-майбутніми архітекторами графічними засобами художнього зображення включає не тільки освоєння академічної грамоти виконання рисунка 3 натури, а передусім пізнання композиційних принципів структурування абстрактних форм. Програмою архітектурної спеціальності «Архітектура та містобудування» не передбачено вивчення курсу «Композиція», необхідність якого очевидна. Тому виникає потреба впроваджувати його у навчальний процес на заняттях з рисунка у вигляді певних композиційних завдань та вправ. Ці завдання виконуються у заданій системі обмежень зображення елементів форми: точка, пляма, лінія, площина, об’єм, простір. Робота над ними регламентується навчальними годинами, більшість із яких відводяться на самостійну творчу діяльність з обов'язковим обговоренням ескізів на індивідуальних та колективних консультаціях. Одним із головних завдань сучасної освіти є якісна зміна системи професійної підготовки фахівців, у якій на першому плані постає ступінь розвиненості мислення, що відповідає якості професійної діяльності. Якісний рівень професійної діяльності майбутнього фахівця мистецької сфери виражається в поєднанні набутих науково-теоретичних знань, умінь і навичок у сфері композиції, а також здатності вирішувати творчі завдання. Тому у процесі навчання студентів композиції формування композиційного мислення $є$ показником якості професійної підготовки, інструментом творчості і засобом становлення творчої особистості. Композиційне мислення є самостійним видом розумової діяльності, оскільки в ньому зафіксовано композиційний розумовий процес із його операціями та його кінцевим результатом, і який слугує основою як для творчого, так і для художньо-образного мислення. Теоретичні знання, які студенти набувають 3 основних тем композиції на заняттях із дисципліни «Рисунок, живопис, скульптура. Рисунок», є вихідною базою для професійного глибокого розуміння законів, принципів і засобів художньо-композиційного формоутворення штучних систем як суттєвої складової професійної грамотності і творчого мислення студента. Ці теоретичні та практичні знання дають майбутньому художнику або архітекторові можливість упевнено судити про естетичну і художню повноцінність творів композиційної творчості, проникати у сутність їхньої гармонійної будови, чітко усвідомлювати механізми впливу таких творів на емоційно-чуттєву сферу сприйняття людини.

Ключові слова: архітектурна освіта, композиція, композиційне мислення, художня освіта, рисунок.

Submitted on March, 22, 2017

Reviewed by Doctor of Pedagogy, prof. O. Shevniuk 